\title{
Cosmopolitans versus the locals: community-based protest in the age of globalisation
}

\author{
MICHAEL MURRAY \\ National University of Ireland, Maynooth
}

\begin{abstract}
Processes of deterritorialisation and cosmopolitanism are, according to some authors, diminishing the influence of location on identity formation in the age of globalisation. This paper disputes these claims by arguing that 'locality', as a social construction, remains a key determinant of identity, especially in relation to community-based protest. In doing so, it draws on a case study of members of a Dublin community who are resisting government plans to locate a municipal incinerator in close proximity to their neighbourhood. An alternative view is offered which employs Roudometof's (2005) concept of a continuum of 'degrees of attachment' and suggests that transnational forces/discourses are 'critically filtered' by members of the community in terms of the primacy of local concerns and meaning.
\end{abstract}

\section{Introduction}

One of the features of globalisation that has been identified by authors is the notion that identity formation is determined less and less by the local. Increasingly, the argument goes, global or transnational 'flows' of discourses and signifiers are shaping how we see ourselves and others. Thus, a 'deterritorialisation' of the local and the national has important implications for how the notion of 'community' is perceived and conceptualised. Instead of identities anchored firmly in a sense of local 'place', communities of 'interest' (virtual or otherwise) herald the advent of a 'cultural disposition' towards a more cosmopolitan outlook (Tomlinson, 1999). As a consequence of this 'transformation', writers such as Beck have claimed that location will become less and less relevant for communities (2002: 31).

Yet, in spite of the pervasiveness of transnational/global influence, evidence from a case study presented here suggests that 'community life' in early $21^{\text {st }}$ century Ireland may well remain the preserve of locality and place. Claims by some authors, particularly supporters of the 'cosmopolitanisation' thesis, exaggerate the effects of transnational processes on communities, basing their arguments on an a priori, and frankly vague, characterisation of the 'local' and the 'cosmopolitan' (Roudometof, 2005). Individuals and communities who refuse or 
are unable to enter into the cosmopolitan agenda are therefore labelled as insular, closed and akin to the 'traditional' (or even the 'unfashionable)' in this age of globalisation.

I argue here that, not for the first time, attempts at airbrushing out the importance of locality or the social construction of 'place', particularly in relation to community-based protest, are somewhat premature. Such attempts are based, amongst other factors, on the deployment of what are essentially 'straw man' opposites - poorly defined polarities of 'local/national' versus 'global/cosmopolitan'.

I begin by looking at how members of a Dublin community are resisting plans to locate a municipal incinerator on their doorstep. The rationale behind looking at this instance of community-based protest is very simple: it offers an opportunity to view, in a very direct manner, the impact of transnational - or global - processes on members of a community. The promise/threat of the introduction of incineration into Ireland has largely been shaped by these transnational processes and discourses. These include the European Union and the machinations of multi-level governance, transnational scientific and technical discourses on incineration, multi-national corporations involved in the waste industry, and the input from transnational Non-Governmental Organisations (NGOs). It can be seen that while these discourses are indeed influential, it is concern for the locality and the welfare of future generations living there that is paramount for residents featured in this case study. ${ }^{1}$

No community can be deemed wholly open or wholly closed to outside influence. However, the notion of a 'closed' community plays a central role, both in the conceptualisation of cosmopolitanism I look at here, and critically, in official attempts to marginalise opposition to the proposed incinerator. In this respect, perceptions of a 'closed' community are compounded by the use of the 'NIMBY' label (Not In My Back Yard), implying that objections to 'outsiders' are based upon irrational and selfish reasons. A second, related issue reflects broader societal power relations. The community in question, Ringsend, is perceived, by the residents interviewed here, and others (including elected representatives), as a working class community. The issue of whether any community, Ringsend or otherwise, can be conceived of a homogeneous 'class enclave' is obviously very debatable, particularly with regard to processes of 'urban renewal' and gentrification. At the same time, there is evidence to suggest that, for instance, Smith's notion of 'revanchism' (1996) has had a limited impact on the socio-economic composition of Ringsend. Data from Dublin City Council's 'Waste to Energy' website and the Dublin City Childcare Committee both cite the Ringsend area as scoring particularly high on deprivation indices, and according to the latter little has changed in this respect since 1991. ${ }^{2}$

However, far from attempting to objectively define Ringsend in class terms, my intention is to show how the perceptions on this issue of residents and other significant actors (government officials, elected representatives) impact on the 'open/closed' debate. This is relevant because authors such as O'Byrne (1997) 
have interpreted such communities as almost instinctively in opposition to 'globalist' or 'outsider' forces. Additionally, there is a strong view held by some residents that official perceptions of Ringsend as a working class area have directly impacted on the location of waste infrastructure in the past, a dubious legacy resulting in health problems for some of its residents today.

Lastly, it is stressed that transnational influences here are critically evaluated or filtered through the primacy of the 'local' by members of the community. While this paper concerns itself with a particular case study, I believe that certain aspects are instructive for broader theoretical debates on the relevance of locality to community identity, particularly in the context of global/transnational processes. In this respect, Roudometof's (2005) suggestion that we should view the importance of locality (as a signifier of identity) in terms of 'degrees of attachment', rather than positing the 'local' in opposition to the 'cosmopolitan/global' (where both are conceived as a priori absolutes) certainly bears relevance and validity here. Roudometof's approach is primarily based on a continuum between the transnational and the local, where the degree of attachment is influenced by the different importance given by individuals to such factors as 'neighbourhood or city', 'state or country', 'attachment to and support of local culture' and 'degree of economic, cultural and institutional protectionism' (Roudometof, 2005: 125-6).

\section{Background to the case study}

The research presented here comes from a study that looked at the impact of transnational forces on Irish political power relations and governance and was conducted between 2000 and 2003. The issue of the introduction of incineration into Ireland allowed for an analysis of the degree to which multi-level governance (transnational, national, sub-national), transnational NGOs, and transnational 'expert' discourse networks can impact at the local or community level. Given the nature of contention over the incinerator issue, as well as the divergent meanings attached to almost all aspects of the governance processes involved, a qualitative approach was employed for the study. The research presented here includes extracts from individual and group interviews with residents from Ringsend (a residential area located in close proximity to the proposed site of the Poolbeg incinerator) elected representatives (councillors, TDs and MEPS), officials (Dublin City Council, Government Departments and the European Commission) and representatives from a transnational NGO. Using a multi-level approach (transnational, national, sub-national), in-depth interviews were conducted with elected representatives from the three levels, officials from the EU's Environment Commission, the Irish Government's Department of the Environment and Dublin City Council. Additionally, interviews were carried out with representatives from transnational, national and local NGOs. ${ }^{3}$ In addition, I conducted participant observation at four meetings of the 'Community Interest Group' (see below), at the launch of the group's report at Dublin City Hall, an anti-incineration protest at 
a DCC-sponsored environmental information 'open day', two meetings of the national network of local anti-incineration groups, as well as two conferences on activism which included various anti-incineration and anti-dump groups, and antibin tax groups.

\section{Ireland, the $\mathbf{E U}$ and the incineration issue}

In the document Environment 2010: Our Future, Our Choice - $6^{\text {th }}$ EU Environment Action Programme, the European Commission states that management of waste is one of its key objectives (European Commission, 2001: 4) and EU legislation outlines a series of targets to be met by member states, particularly on the amount of waste to be diverted from landfill sites. The primary legislative response of the Irish government to EU waste obligations was the introduction of the Waste Management Act (1996). ${ }^{4}$ The then Environment Minster, Noel Dempsey, expanded on the objectives of the 1996 Act in his policy statement Waste Management: Changing Our Ways (Dempsey, 1998) which favours 'Waste To Energy Incineration' (WTE) as a way of diverting over 70 per cent of municipal waste away from landfill. The extent of the problem of waste management facing Ireland is considerable, according the Environmental Protection Agency. It has been estimated that in 2001 it amounted to 0.37 tonnes per person and that this figure has been steadily increasing every year since then. ${ }^{5}$ In addition, EU legislation has set the target of reducing waste going to landfill by 50 per cent by 2050 (Murray, 2006a: 107). Given the nature of the problem and the need to fulfil obligations under EU law, government and local officials I interviewed made a very strong argument that the use of incineration was essentially 'foisted' upon them as the only viable way of meeting waste targets (Murray, 2003: 162-7). Whether this argument is legitimate or not is of course debatable; engaging in a 'blame game' with Brussels is hardly a new development in any member state's relationship with the EU, particularly in relation to controversial and unpopular policies. However, an alternative argument can be made that utilising incineration technology - and other so-called 'end-of-pipe' options - minimises the cost of waste towards the biggest producers, such as the industrial sector, and therefore maintains Ireland's economic competitiveness (Murray, 2006a).

The Minister predicted local resistance to government policy in the Changing Our Ways policy document and this proved to be prophetic. Opposition was concentrated around the issues of the siting of regional 'super-dumps', the proposed sites for incinerators and the introduction of domestic waste charges. In 2000, the NGO Friends of the Earth listed the names of fourteen different waste and anti-dump groups campaigning locally in Ireland (Friends of the Earth, 2000: 3).

In 1999, four potential sites were selected by Dublin City Council (DCC) as a possible location for an incineration plant, out of which Poolbeg was identified as the preferred site. Poolbeg is located close to the residential area of Ringsend in Dublin. A community located just to the south east of Dublin city centre, Ringsend 
has had the dubious distinction in the past of playing host to a number of waste facilities and heavy industries in its immediate locality, including a landfill site and an unlicensed incinerator that was forced to close down by a court order in 1994.

A feasibility study for the introduction of incineration in Dublin region stated clearly that '...public opposition is likely to develop... once a site has been identified' (M..C. O'Sullivan et al., 1999: 79). It was recommended that the public should not therefore merely be 'consulted' in this process, but should be involved in an interactive relationship with the authorities. This process should attempt to include 'those who oppose waste disposal solutions' (M. C. O'Sullivan et al., 1999: 84). However, the only significant public consultation process turned out to be the 'Community Interest Group' (CIG). This initiative was designed by DCC to give an opportunity for residents to put their concerns about the incinerator proposal to a selection of experts. These concerns would then be addressed in any future Environmental Impact Assessment (EIA). Residents from both Ringsend and Sandymount volunteered to be part of the CIG and the process lasted from October 2001 to October 2002 . However, the initiative was roundly dismissed by residents - including the CIG itself - and by elected representatives as little more than a public relations exercise entered into by the government and DCC in order to 'rubber-stamp' all key decisions that had already been taken on the incinerator prior to the consultation. The views of residents were presented in a highly critical report:

On some occasions the CIG have felt that they are wasting their time, especially when they hear that the City Manager had the ultimate decisionmaking powers in this situation. They wonder what is the point of engaging in a consultation exercise if the results of their deliberations do not go towards influencing a final decision (Mercator Marketing Research, 2002: 22).

This one and only attempt at a public consultation process must also be seen in the context of relevant legislation, most notably the 2001 amendment to the 1996 Waste Management Act which removed all decision-making powers from elected representatives, transferring them instead to County and City Managers. This has effectively left the most affected communities with no voice in this vitally important policy area. But this lack of participation - or representation - within the governance processes in relation to the incinerator is not just a local or national issue, it is a transnational one. The opaque nature of decision-making processes within the EU in shaping legislation, setting targets and defining preferred waste management options, the complexity of multi-level governance, the reliance on stakeholders and the aforementioned 'blame game', all contribute to criticisms from both outside and within European institutions, particularly in relation to issues of transparency and accountability (Murray, 2003).

In 2003, Environment Minister Martin Cullen introduced measures under the Protection of the Environment Act that further strengthened the powers of City and County Managers in relation to waste policy. DCC spent much of 2004 
submitting an Environmental Impact Statement for approval to the planning authority, submitting a licence application to the Environmental Protection Agency (EPA), as well as submitting an application to the Commission for Energy Regulation. ${ }^{6}$ They also conducted a number of 'information sessions' with the public on various aspects of incineration. The tendering process to find a commercial operator for the incinerator started in 2005.

Opposition to incineration and super-dumps continues countrywide. For their part, the residents of Ringsend remain implacably opposed to the incinerator plan. In February 2003, DCC held an 'open day' in Ringsend in order to outline its plans for the incinerator. The event was picketed by members of the community and at the same time, plans were announced by one member of the community to take their fight over the incinerator to Europe. ${ }^{7}$ While the statutory process has begun in earnest, there has also been an increase in protest activity from the residents, with a number of public demonstrations taking place over the summer of 2006. In April 2007, the hearings of An Bord Pleanála in relation to planning permission for the incinerator began. The ultimate outcome is still unclear, with the hearings having received almost 3,000 submissions and with the persistence of questions over the tendering process and concentrated opposition from elected representatives.

\section{Placing the cosmopolitan in the urban community}

According to Held et al., globalisation constitutes 'a central driving force behind the rapid social, political and economic changes that are reshaping modern societies and world order' (1999: 7). This 'historically unprecedented' stage in human history obviously has significant ramifications in all spheres of human activity. The infusion of global flows of discourses, people, money, military power and cultural signifiers has resulted in the dilution in the importance of hitherto established sites of identity formation. The demise in the relevance of nationallybased identities, results, we are led to believe, in the emergence of identities formed from non-locationally determined 'interests'. These interests can include gender identity, sexual identity, ethnic identity, political issues, consumer issues, and environmentalism to name a few instances. The accumulation of 'risks' from global modernity (Beck, 1997) have, in their scope, transcended the nation state a facet of the global age that citizens are apparently all too well aware of. Likewise communities, like all societal structures, have undergone transformations. Economic migration (both in and out of communities), reconfigurations in type and location of industry, a shifting in the power structures of multi-level governance, even the growth in use of information technologies (IT) contribute to a fundamental reconsideration of the importance of the 'local' in identity formation.

The urban as a site for global relations is a well-established phenomenon in academic literature - epitomised in the notion of the 'global city' (for instance see Eade, 1997; Clark, 1996; Borja and Castells, 1996). Additionally Clarke postulates that the 'urban world' is increasingly fundamental in shaping contemporary social relations and certainly the Dublin metropolitan area has grown at a rapid pace in 
recent times. In this context, urban communities find themselves as recipients of transnational flows, where the urban exhibits an increasingly homogenised and globalised tendency:

The contemporary urban world is more than a motley assemblage of diverse settlements. Many observers argue that it is slowly becoming a unitary and uniform place, a global city in which most of its inhabitants are imbued with a similar'set of all-encompassing urban attitudes and values, and follow common modes of behaviour. (Clark, 1996: 3)

The global city thesis itself is, of course, not without its detractors and one pertinent criticism in the context of the argument presented here is that 'interest in the global has undermined attentiveness to local and national - especially political processes which determine the fortunes of global cities' (Robinson, 2005: 757). This interest in the global, at the expense of the local, is, I argue below, mirrored in deficiencies in the 'cosmopolitan' framework.

A major consequence of global processes, according to this conceptualisation, is the fact that communities and the local are determined less by the physical boundaries of locality and more with common identity, which is found in the myriad flows of discourse, ideas and signifiers that pervade the global. For instance, for Tomlinson the 'complex connectivity' of globalisation threatens the local through 'multiform penetration' because 'it undermines the thinking through which culture and fixity of location are originally paired' (1999: 28). This results in a process of 'deterritorialisation', which involves 'the simultaneous penetration of local worlds by distant forces, and the dislodging of everyday meanings from their "anchors" in the local environment' (1999: 29). Likewise, Albrow et al. look at how community is becoming increasingly 'disembedded' in the global age where " $[t]$ he construction of "community" in a specific locality ... cannot be analysed on the assumption that the local is prior, primordial, more "real"' (1997: 24). Instead, the authors point to the growing importance of 'imagined communities', where

The shift to seeing the imagined community as the guiding principle for lived social relations represents an important step towards the disembedding of community, for it opens the possibility of representing the absent and distant as being integral to the local (Albrow et al., 1997: 23).

The notion of 'deterritorialised' communities and localities brings us to the argument that 'communities' are increasingly being formed and negotiated through shared values ideas and identities. In the global context, the logic of this transformation is a 'cultural disposition' (Tomlinson, 1999) towards cosmopolitanism or 'citizenship of the world' rather than identity anchored to a locality, where 'what ordinary people think, believe and do in their local situations counts in the sphere of global governance' (Tomlinson, 1999:183). 
Cosmopolitans are open - open to cultural difference (Tomlinson, 1999: 195), open to outside influence and, crucially, open to non-locational identity formation. Cosmopolitanism is:

an imagination of alternative ways of life and rationalities, which include the otherness of the other. It puts the negotiation of contradictory cultural experiences at the centre of activities: in the political, the economic, the scientific and the social (Beck, $2002: 18$ ).

This is contrasted with identities that revolve around 'nationalism'. For instance, Beck (2002) argues that while 'cosmopolitanisation' is characterised by inclusion of different cultural perspectives, 'nationalism' is all about excluding others. In fact, Beck alludes to 'nationalism' as being one of the main 'enemies' of cosmopolitanism (2002: 38).

However, it is the significance of the local in identity formation that is crucial in ascribing a fate to 'community' in the global age. While Beck acknowledges that the local retains at least some relevance - 'there is no cosmopolitanism without localism' (2002 : 19) - this particular 'glocalisation' can be fairly criticised for its theoretical vagueness and lack of specificity, in the same way that Hannerz has written critically of a 'global babble' - a 'tendency to resort to hyperbole and excessive generalisations, to tell a story of dramatic shifts between "before" and "after"' (1996: 18). ${ }^{8}$

It is the construction of a polarity between, on the one hand, the cosmopolitan/global and, on the other, the national/local, which is critically important here. If people more and more identify themselves outside of the traditional sites of identity formation (Beck, 2002: 31) there is one logical outcome for the relevance of 'community' in these people's lives: 'community life will no longer be determined solely or even primarily by location' (Beck, 2002: 31 ). Elsewhere, Hannerz somewhat more cautiously asserts that 'the one and only local would appear to be a rather less privileged site of cultural process' (1996: 28).

In the absence of empirical evidence to reinforce the cosmopolitan thesis, it would appear that authors are content to see cosmopolitanism more as a desirable goal or aspiration for human development (Sklair, 2002; Tomlinson, 1999) or as a 'methodological concept' (Beck, 2002: 18). However, this point actually remains elusive in the literature, because Beck (2004) does not offer empirical evidence to support his position. As Roudometof suggests, Beck

moves back and forth between sociological description and prescriptive moral argument; this does not allow for an effective conceptual separation between cosmopolitanism as a moral or ethical standpoint and cosmopolitanism as a real, empirical variable. (Roudometof, 2005: 117) 
As already suggested, a key problem with this cosmopolitan position is that it relies on the construction of false polarities. Essentially it claims that one discourse is characterised by inclusion or openness, while the other represents exclusion and isolation. Beck's argument rests upon the claim that 'nationalist' discourses are, by their nature, 'globalphobic' (2002: 38). This view assumes that firstly, cosmopolitanism (according to Beck's conceptualisation) is global identity and culture, and secondly, that there exist 'hermetically sealed' local or national identities (Hubbard et al., $2002: 223$ ).

Both assertions would be difficult to sustain under scrutiny. For instance, some 'nationalist' discourses seek to actively broaden the level of participation at a transnational level, as is the case with diaspora-based communities. This in itself could be construed as reflecting both a nationalist identity and a transnational identity. Equally, it can be argued that cosmopolitanism and nationalism are not fixed and mutually exclusive identities to which individuals are bound in all aspects of life. Surely.it is feasible that the same individual might identify with the nation state as the primary site of political authority but, at the same time, identify with transnational discourses on, for instance, the environment or workers' rights.

As we will see, this would appear to be the case with respect to the residents of Ringsend interviewed here. It is the conceptualisation of what constitutes either a 'cosmopolitan' or a 'local' that is crucial. As Roudometof suggests (2005: 122), 'it is entirely possible that individuals are not going to develop profiles that will conform to the stereotypes of cosmopolitan and local'. It is the degree of 'meaning' that individuals give to, for instance, their local community that is paramount:

It is a foregone conclusion that different individuals' sentiments would vary depending upon the particular dimension they feel is most important for themselves and others (Roudometof, 2005: 125).

The local as a socially constructed 'place' continues to be of primary importance, even in the age of globalisation. 'Place' provides both physical and geographical references for identity formation, as well as invoking a sense of shared history and culture. Gupta and Ferguson argue that notions of identities conceived in the context of the 'local' are neither wholly chosen, wholly determined, nor for that matter in any way permanent. They suggest that 'place making' involves 'a construction, rather than merely a discovery' (Gupta and Ferguson, 1997: 13). It must be emphasised however, that this construction is not just the sum of the choices and activities of agency - a central implication of the 'communities of interest' thesis. Instead, 'place making' (and its subsequent effect on identity formation) is itself the result of power relations (Massey, 1999: 291; Castells, 1997: 7). While constructions of place are 'relational and contingent, [and] experienced and understood differently by different people' (Hubbard et al., 2002: 18 ), their continuing relevance should not be underestimated. 


\section{Community resistance against the incinerator: the social construction of locality}

The residents interviewed for this study had lived in Ringsend all of their lives. In some cases, multiple generations of the same family lived in the locality. All of the Ringsend residents identified themselves as 'working class' and also perceived this as a reason why Poolbeg was selected as the site for the incinerator. It was clear from the views expressed in interviews that they believed that maintaining their sense of 'community' in the face of powerful outside forces was of paramount importance. For these respondents, it is clear what their community means to them.

It's a closely-knit community and people do pull together, especially when they need to. I know you go into some areas and say 'oh no', but this area is a great area. When you have great people working around you ... not politicians, I'm talking about people in the community themselves who work for the community.

One respondent commented that '.. the whole purpose of community is continuity and it takes hundreds of years for communities to develop'. It is certainly true that some families have lived the area for generations and this is an essential element in the construction of 'place'. Family networks are seen by some of the residents interviewed as a significant determinant in the development of the community and therefore as a 'community of fate' (Logan, 1978: 408).

Concern or fears generated particularly by the introduction of certain infrastructure or 'development' is a key factor in driving activism for some members of the community. This is one context where the social construction of place becomes an arena for power relationships, where '...the effects of collective memory, imaginaries and institutions ... can be understood as solidifying configurations of "social relations", "material practices", elements in "discourse" and forms of "power"" (Sharp et al., 2000: 25). Frequently, activism comes about as a result of a threat to everyday quality of life. One resident, who is also a community activist, said that she originally got involved because of 'small things, like footpaths'. In such situations, some in the community felt that they could not rely upon formal political power structures in order to ensure that they would have a substantial say in future developments. Becoming a community activist was a case of 'having to', according to one respondent.

That concern for the community and locality is the first priority here is not in any doubt. However, it was made clear in the course of interviews that it is a concern not just over 'control of space' (associated with isolationist 'localism'), but 'control of time', the concern for preservation of the environment and future generations (Castells, 1997: 62), that motivates resistance to the Poolbeg incinerator. One community activist commented - 
I've two children, they're teenagers now and I just think of them and I think about what's around the next corner for them, how are they going to have their children, how are they going to have a home, how are they going to live in a safe, clean air environment ...

\section{'Not in my back yard' or 'Not in anybody's back yard'?}

The perceived polarity between a cosmopolitan and a local disposition is centred on the notion that the cosmopolitan is open, inclusive and dynamic, while the local is conceptualised as closed, 'traditional' and isolationist :

Living in a transnational world, individuals can adopt an open, encompassing attitude or a closed, defensive posture. In the first case, individuals are labelled cosmopolitans; while in the second cases they are labelled locals ... These attitudes can be extremely influential in a whole array of topics, ranging from terms of trade to support for fundamentalist organisations to attitudes about religion or culture to expressions of tolerance or hostility towards immigrants (Roudometof, 2005: 121).

This localism is a defensive formation against 'the impositions of global disorder and uncontrollable, fast-paced change ...' (Castells, 1997: 64). Nowhere is this defensiveness more pronounced than in the NIMBYist position. The NIMBY label is habitually levelled at those communities who oppose any developments in their locality, but in recent times this discourse has been associated by the government - and sections of the news media - with communities who oppose the more controversial aspects of waste management policy, particularly in relation to the location of regional 'super-dumps' and municipal and hazardous waste incinerators. ${ }^{9}$ On one occasion, the then Minister for the Environment Noel Dempsey accused elected representatives in engaging in a 'parish-pump mentality' in relation to the stalling of waste management plans. In addition, the Minister stated:

I believe we have come to a point where we must shout 'stop' to focus group politics and look towards unpopular possibilities if they are the right option (Irish Independent, 25 August, 2001).

This construction of NIMBYism has obvious similarities with Beck's (2002) construction of the local and 'national' disposition, outlined above. The implication is that objections made by these groups are only on the basis of irrational discourses of self-interest, that they do not object to incineration in principle, as long as the incinerator is not located on their doorstep. In particular, according to critics, what is really of concern to the anti-incineration groups is maintaining the capacity to maximise the value of their own properties. This has echoes of Dye's conceptualisation of 'community power': 
Community power structures are composed primarily of landed interests whose goals are to intensify the use of their land and add the value to it ... community elites seek to maximise rents rather than profits (Dye, 1986: 31 ).

In fact, officials like to ascribe another acronym to refer to this attitude BANANA: 'Build Absolutely Nothing Anywhere Near Anyone'. This rejection out of hand of all development includes, according to one DCC official, any waste infrastructure, even those associated with recycling:

We cannot site a bottle-bank in this city. The objections are absolutely phenomenal. Nobody wants anything near him or her. Bottle-banks, Bring Centres, composting facilities, they don't want compost bins, don't want to pay for their waste, sick of the green bins taking up too much space ...

On incineration, one government official said:

Because waste is such a sensitive area and a lot of people just don't understand what's involved, you could say to someone 'thermal treatment equals incineration equals cancer factory' and no matter what level of debate, no matter how much money you plough into advertising, no matter if you take them abroad and bring them to highly urbanised facilities in London or central Europe, you won't convince them. So I think there is some genuine fear and misunderstandings to what's involved and why. When you say 'incineration', you probably, even myself, imagine a chimney stack that is 30 years old, spewing out ...

The accusation of NIMBYism based on irrational fears was levelled against community opposition by both DCC and Department of the Environment officials. But characterising communities such as Ringsend as merely defensive and NIMBYist does the residents of that community a great disservice. In the case of Ringsend, the NIMBY label, as well as marginalising any objections (legitimate or otherwise) to government plans, fails to take account of the painful legacy of other undesirable infrastructures in the locality, and their impact on attitudes to the proposed incinerator. Certainly, the community of Ringsend has had extensive experience of hosting or being in close proximity to dubious waste installations in the past. This has included a landfill site, an unlicensed/illegal incinerator, a private waste management company and currently, a major sewerage works. Put simply, rather than being closed to hosting such infrastructure - the central element of the NIMBY discourse - the community of Ringsend have been all too open to these developments. A locally elected TD concluded:

NIMBYism in relation to the incinerator is not really on. If you look at the Ringsend-Sandymount area, they have the Dublin port, they've concrete 
waste, they've sewerage treatment, they've the ESB, they've Hammond Lane, they've Al waste, and the list runs on. So, robbing somebody else's quote... its not NIMBYism, its not in my back garden, my back yard is full in the Ringsend-Sandymount area ...

The charge of NIMBYism is also premised on the idea that residents' objections are based on the location of undesirable waste infrastructure, not the efficacy of the deployment of specific technologies. This is a critical point. Residents would strongly object to this view and in doing so, exhibit an openness to outside influence and discourse. Residents have utilised transnational expert knowledge networks, for instance in the employment of alternative discourses on waste management, as well as taking advantage of resources offered by transnational NGOs in order to fight any future campaigns.

Another decisive element in the construction of an open/closed or local/ cosmopolitan dynamic is class. While perceptions of what constitutes 'community' are developed through a myriad of elements - including a shared sense of history or kinship networks as I have already mentioned - the issue of class plays a key role: 'Place of residence itself affects the chances for social rewards to the degree that persons are tied to the advantages and disadvantages of places' (Logan, 1978: 408). Additionally, class, according to some authors, affects dispositions towards global flows, and by implication, I would argue, the construction of a cosmopolitan outlook. O'Byrne, in a study of a working class community in London in the 1990s, found evidence to support the argument that working class communities are historically closed to 'outsiders':

Working class communities have always abounded with conflicts between 'insiders' and 'outsiders'... These struggles are political struggles, be they between black and white, rich and poor, local and global ( $\mathrm{O}$ 'Byrne, in Eade (ed.), 1997: 87).

This defensive posture must, according to O'Byrne, be viewed in the context of wider power relations and critically, global or transnational forces: working class communities 'produce a conscious resistance to external forces and a mistrust and rejection of globalist values in favour of a defence of local activity' (ibid: 74).

However, assigning such features to working class communities per se is pandering once again to the a priori polarities of 'cosmopolitan/local', 'open/ closed,' or even 'dynamic/traditional'. According to residents and elected representatives interviewed, it is precisely because Ringsend is perceived as 'working class' by officials, that it has been susceptible to hosting of waste infrastructure in the past. In this respect, working class communities do not stand in some sort of splendid isolation - the opposite is true. Such communities are selected to host these developments specifically because they are seen as working class and therefore, are perceived as weak when it comes to exercising political, social and 
economic power. An MEP interviewed suggested that more affluent areas are not considered for siting because 'these areas will have a lot more clout'. She thought that, in considering potential sites, officials calculated 'who will be opposing it in that area and how much clout, money, power and influence have they got'. One resident suggested that the reason why Poolbeg was chosen as a site for the incinerator was because 'they [DCC] think it's a working class area and a soft option'. Another Ringsend resident stated:

The attitude you get from officials who push you down if you try to protest is that somehow ... you're stupid, you don't know what you're talking about. That's because they equate this area as a working class area ... they equate your intelligence with your income and your social class.

The inaccuracy of the characterisation (by government and local authority officials) of the Ringsend residents' opposition to the incinerator as NIMBYist and solely concerned with 'defence of space' is illustrated in their involvement in other anti-incineration campaigns around the country. Almost all of those residents interviewed who were opposed to the proposed Poolbeg incinerator were clear that not only did they not want to have incineration in their area, they do not want to have it introduced into Ireland at all. Or, as a representative from the EPA put it, "the "Not In My Back Yard" syndrome had been added to in recent times with "Not Over There Either"'. This view was echoed by one resident: 'I don't think anyone in this area has ever said "no" to waste management. All they're saying "no" to is incineration. People are forgetting that.' Additionally, some residents have become active in networks of other locally based anti incineration campaigns - yet another indication of openness to 'outsiders'. This prompted another TD to comment:

I think there are individuals in those communities that have a wider view and a wider vision and while they perhaps oppose a particular development within their neighbourhood, I think many of the individuals involved in these NGOs or local groups are concerned about the wider picture and they see the local issues symbolising the...problems in national policy or countywide policy.

\section{Neither 'cosmopolitan' nor 'NIMBY': critically filtering transnational discourses through the primacy of location}

As we have seen, in an echo of the 'cosmopolitan/local' construction, O'Byrne (1997) argues that working class communities reject 'globalist values in favour of a defence of local activity'. In the case of the Poolbeg incinerator, this is a contentious claim. It was mentioned above that in the course of organising community awareness on the government's proposal for the incinerator, activists made use of both transnational discourses on incineration that emanated principally 
from transnational NGOs, and of the NGOs themselves. In other words, there was little evidence of reticence on the part of members of the community in reaching out to 'outsider' help, if this would be useful in resisting the incinerator.

What is observable, however, is that residents 'critically filter' the impact that transnational factors have on their resistance to the incinerator and that the primary determinant in this case is attachment to the local. Essentially, global/transnational flows are negotiated in this context. The idea of 'flows', whether through expert knowledge networks of pro/anti incinerator discourses, governance, economics, or otherwise, is according to Castells central to social organisation in the global world: 'The space of flows is the material organisation of time-sharing social practices that work through flow' (2000: 442). However, the actual degree of influence of these discourses at the community level may not be as profound as Castells suggests.

This is certainly the case when the relationship between transnational NGOs and community-based activists is examined. One transnational NGO was invited to speak to residents very early on in campaign planning. This NGO's core message was to directly link local action with global problems. One transnational NGO representative remarked that 'there is also a big global picture going on as well and we're very well aware of that'. This notion of 'supraterritorial solidarity' is seen as a prerequisite for the emergence of a global civil society (Scholte, 1999: 10) and epitomises the cosmopolitan 'cultural disposition'. However, the NGOs have met a considerable degree of resistance from members of the community in this respect. Some Ringsend residents felt that the bigger NGOs were more interested in promoting their own agendas when they assist local campaigns. One resident thought that the transnational NGO was merely using the local protest in order to fuel their own global campaign. Another resident agreed with this assertion: 'I don't know, I'm a bit dubious about them [the transnational NGO] to be honest with you. I mean, I'm sure they have their own agenda too.'

Significantly, some respondents, while grateful for any help that the NGO could give them, resented the idea that members of the Ringsend community had to be made aware of wider dimensions to the debate on incineration by the transnational NGOs. One commented:

From our point of view, even before Friends of the Earth or anyone came down to us, we were saying 'its not just about Ringsend, this is a wider issue anyway'. I think they do help in a sense but I think in another sense, it can hinder, you know.

Certainly, while there were some in the Ringsend community who would wholeheartedly agree with the transnational NGO as regards linking the local with the global, not everybody agreed that it was an important issue in the context of the campaign. Community activists were all too aware of the potential of the power relation between themselves and the NGO. While they had little option in relying 
on the NGO for crucial support (resources/expert discourses), it was made clear to the NGO that it was locals and not the NGO that were running the campaign. One resident stated: 'I wouldn't be used by anybody, whether it be a politician, a 'councillor, an official or an NGO ... I mean, we're not stupid ...'

Accusations of attempting to dominate local campaigns to further its own ends led the transnational NGO to rethink its strategy in relation to local groups. Previous practice was for the NGO itself to run the local campaign, with the effect that the community was virtually marginalised. One NGO representative commented:

Initially we thought here that we could sort of run it on our own, sort of run general campaigns based on general structures around the issue, get a poster campaign going ... get the media on top of it and work as sort of an umbrella organisation if you like, and leave the communities out of it.

A key factor in changing this approach was that residents simply did not agree with the degree of emphasis that the NGO attached to its global agenda. The fundamental shift in strategy resulted in the situation whereby the NGO took on the primary role as a repository for expert knowledge, on request from the community. This is the view of a NGO representative:

Well basically what's happening with Ringsend is that ... they're not asking us to run the campaign at all. What they're asking us for is factually, solidbased documentation.

\section{Conclusion}

On the basis of the case study examined here, the fundamental argument offered is that, contrary to the deterritorialisation and cosmopolitan arguments, the social construction of 'place' and the local community remains a primary source of identity formation in the age of globalisation. Critically, however, neither 'ideal type' of 'cosmopolitan' or 'local' satisfactorily encompasses the position taken by residents of the community of Ringsend in relation to the incinerator. This is primarily because many of the claims of cosmopolitanisation resort to crude generalisations and remain largely aspirational. The crude dichotomy of 'open/ closed' or cosmopolitan/local does not bear up to scrutiny in this particular case. This is particularly true in relation to the NIMBY discourse and issues of class discussed above. Instead, transnational discourses and processes are critically filtered by members of the community in question, where it is the degree of attachment - in this case to the locality - that determines the acceptance or rejection of these discourses and processes. 'Community' or 'locality' is never fixed in terms of meaning, as the cosmopolitan thesis proposes; but this is not the same as suggesting that their importance is wholly negotiable too. 
Undoubtedly there are those whose identities are far less determined by place or national identity, but I suggest that this is hardly a new development in human societies. Certainly, some sections of society have more capacity than others to engage with transnational or global discourses. In fact, Roudometof points out that some authors see cosmopolitanism as the 'manifestation of the mentality of the upper and middle classes' (2005: 113). More useful in understanding the observations made in this case study is Roudometof's conceptualisation of transnational/ local interaction. It will be recalled that from this perspective the key to distinguishing the degree of outsider or transnational 'reach' in relation to community/ individual identity is the degree of attachment 'to cultures, locales and regions' (2005: 113). This is best conceptualised as a continuum:

[A] continuum that consists of different degrees of attachment allows the researcher to view cosmopolitan and local dispositions as a relationship of degrees, and not as absolutes. Moreover, it allows reserving judgement about outcomes: no a priori decisions are made about the validity of such a conceptualisation (Roudometof, 2005: 123).

The argument offered here, in keeping with the findings of the case study, is similarly that we should pay attention to the degree to which transnational forces impact on the local. All in all, there is little evidence to support Beck's claim that the vitality of 'community life' and identity is undergoing a radical change in the age of globalisation.

\section{Notes}

1 While this article examines a community-based protest, the focus is not on the organisation of the protest and therefore I do not address the substantial literature and debates relating to social movements.

2 See DCC's 'Data on existing health in the community' at http://www.dblinwaste toenergy.ie/files/july-2006/appendix/ Appendix_13_4_Data_on_existing_health_in thecommunity.pdf and Dublin City Childcare Committee Ltd's 'Childcare Audit and Needs Analysis 2006' at www.dublin.ie/uploadedFiles/Childcare/Dublin\%20 South\%20East\%20.pdf 3 In total, 28 in-depth interviews and two group interviews were conducted between 2000 and 2003. The interviews themselves were conducted in residents' homes, elected representatives' offices, official buildings in Dublin and Brussels and a public meeting. Each interview was fully transcribed and coded.

4 This incorporated the EU 'waste hierarchy' into Irish law and set out regulatory powers for the Minister in relation to the prevention, minimisation and recovery/recycling of waste streams. As part of this legislation, local authorities were obliged to draw up waste management plans and strategies, either individually or, as in the case of Dublin, regionally in conjunction with neighbouring authorities.

5 See www.epa.ie for more details.

6 See http://www.dublinwastetoenergy.ie/ 
7 Evening Herald, 21 February 2003.

8 Other authors such as Held et al. (1999) and Robertson (1995) offer a more detailed schematic of the relationship between the 'global' and the 'local', particularly in relation to the concept of 'glocalisation'. This theoretical construction is not without its own difficulties.

9 For instances of this, see The Irish Times (19 March 2005); The Irish Examiner (6 December 2000, 3 November 2000, 9 December 2004). For a discussion of this, see Murray (2006b); Fagan et al. (2001).

\section{References}

Albrow, M. 1997 'Travelling beyond local cultures: socioscapes in a global city', pp. 37-55 in J. Eade (ed.), Living in the Global City: Globalisation as a Local Process. London: Routledge.

Beck, U. 1997 Risk Society: Towards a New Modernity. London: Sage.

Beck, U. 2002 'The Cosmopolitian Society and its Enemies', Media, Theory \& Society 19 (1-2): 17-44.

Beck, U. 2004 'Cosmopolitical realism: on the distinction between cosmopolitanism in philosophy and the social sciences', Global Networks 4 (2): 131-56.

Borja, J. and Castells, M. 1996 Local and Global: Management of Cities in the Information Age. London: Earthscan Publications.

Castells, M. 1997 The Power of Identity. Oxford: Blackwell.

Castells, M. 2000 The Rise of the Network Society. Oxford: Blackwell.

Clark, D. 1996 Urban World/Global City. London: Routledge.

Dempsey, N. 1998 Waste Management: Changing Our Ways. Dublin: Department of the Environment and Local Government.

Dye, T.R. 1986 'Community Power and Public Policy', pp. 29-51 in Waste, R. (ed.), Community Power. London: Sage.

Eade, J. (ed.) 1997 Living in the Global City: Globalisation as a Local Process. London: Routledge.

European Commission 2001 Environment 2010: Our Future, Our Choice - $6^{\text {th }}$ EU Environment Action Programme. Luxembourg: Office for Official Publications of the European Communities.

Fagan, Honor, Denis O'Hearn, Gerard Mc Cann and Michael Murray 2001 Waste Management Strategy: A Cross Border Perspective. NIRSA Working Papers series, 2aDec 01. Funded by the Centre for Cross Border Studies, Armagh.

Friends of the Earth 2000 Earthwatch: The Irish Environmental Magazine. Issue 49, Summer. Gupta, A. and Ferguson, J. 1997 Culture, Power, Place. Durham, NC: Duke University Press. Hannerz, U. 1996 Transnational Connections. London: Routledge.

Held, D., A.G. McGrew, D. Goldblatt and J. Perraton 1999 Global Transformations. Cambridge: Polity. Hubbard, P. J., R. Kitchin, B. Bartley and D. Fuller 2002 Thinking Geographically. London: Continuum.

Logan, J. 1978 'Growth, Politics, and the Stratification of Places', American Journal of Sociology 84 (2): 404-16.

Massey, D. 1999 'Spaces of Politics', pp. 279-94 in D. Massey, J. Allen, P. Sarre (eds), Human Geography Today. Cambridge: Polity Press. 
M. C. O'Sullivan (consultants) et al. 1999 Feasibility Study for Thermal Treatment of Waste for the Dublin Region. Dublin: Department of the Environment and Local Government. Mercator Marketing Research 2002 'Record of Findings of the Ringsend CIG.' Prepared by Mercator Marketing Research on Behalf of Ringsend CIG.

Murray, M. 2003 Waste Management in Ireland: A Case Study on the Impact of Transnationalisation on Governance. Unpublished PhD thesis, NUI Maynooth.

Murray, M. 2006a 'The Polluter Pays? Individualising Ireland's Waste Problem', pp. 103-14 in M. Corcoran and M. Peillon (eds), Uncertain Ireland: A Sociological Chronicle 2003-2004. Dublin: Institute of Public Administration.

Murray, M. 2006b 'Multi-level "Partnership" and Irish Waste Management: The Politics of Municipal Incineration', Economic and Social Review 37 (3): 447-65.

O'Byrne, D. 1997 'Working class culture: local community and global conditions', pp. 73-89 in J. Eade (ed), Living in the Global City: Globalisation as a Local Process. London: Routledge.

Robertson, R. 1995 'Glocalization: Time-Space and Homogeneity-Heterogeneity', pp. 25-44 in M. Featherstone, S. Lash and R. Robertson (eds), Global Modernities. London: Sage.

Robinson, J. 2005 'Urban Geography: World Cities, or a World of Cities', Progress in Human Geography, 29 (6): 757-65.

Roudometof, V. 2005 'Transnationalism, Cosmopolitanism, and Glocalization', Current Sociology 53 (1): 113-35.

Scholte, J. 1999 'Global Civil Society: Changing the World?', Working Paper No. 31/99.

Centre for the Study of Globalisation and Regionalisation, University of Warwick(www.warwick.ac.uk./fac/soc/csgr): Accessed 12 February 2001.

Sharp, J., P. Routledge, C. Philo and R. Paddison (eds) 2000 Entanglements of Power: Geographies of Domination/Resistance. London: Routledge.

Sklair, L. 2002 Globalization: Capitalism \& its Alternatives. Oxford: Oxford University Press.

Smith, N. 1996 The New Frontier: Gentrification and the Revanchist City. London: Routledge.

Tomlinson, J. 1999 Globalisation and Culture. Cambridge: Polity. 
Copyright of Irish Journal of Sociology is the property of Irish Journal of Sociology and its content may not be copied or emailed to multiple sites or posted to a listserv without the copyright holder's express written permission. However, users may print, download, or email articles for individual use. 